Слабкий Г.О., Миронюк І.С., Білак-Лук’янчук В.Й.

\title{
Щодо оволодіння магістрами теоретичними та практичними компетенціями відповідно до основних оперативних функцій громадського здоров'я
}

\author{
ДВНЗ «Ужгородський національний університет», м. Ужгород, Україна \\ g.slabkiy@ukr.net, ivan.myronyuk@uzhnu.edu.ua, bilak.vika@gmail.com
}

Слабкий Г.А., Миронюк И.С., Билак-Лукьянчук В.И.

Вопросы овладения магистрами теоретическими

и практическими компетенциями в соответствии с основными оперативными функциями общественного здоровья

ГВУЗ «Ужгородский национальный университет», г. Ужгород, Украина
Slabkiy G.O., Myroniuk I.S., Bilak-Lukianchuk V.Y. On mastering theoretical and practical competencies by the masters according to basic operational functions of public health

SU "Uzhhorod national university", Uzhhorod, Ukraine

\section{Ветуп}

Перед Україною стоїть задача впровадження в системі громадського здоров'я основних оперативних функцій громадського здоров'я, визначених Всесвітньою організацією охорони здоров'я відповідно до “Свропейського плану дій по зміцненню потенціалу та послуг охорони громадського здоров'я” [1]. При цьому слід зауважити, що система громадського здоров'я має включати надання як індивідуальних, так і громадських послуг населенню на національному, регіональному та місцевому рівнях та вживати заходи, які впливають на організацію діяльності інших галузей (міністерств, держкомітетів, держслужб. агенцій та ін.). Важливо приділяти увагу соціальним, екологічним та економічним детермінантам здоров'я, керуючись підходом “охорона здоров'я в усіх політиках держави”, що має бути загальнодержавним принципом визнання пріоритетності забезпечення безпеки в питаннях життя і здоров'я людини, безпечного середовища іiі життєдіяльності перед будьякими іншими інтересами й цілями у сфері господарської діяльності; функціонування суспільства на засадах сталого розвитку [2].

Розпорядженням КМУ від 30 листопада 2016 р. № 1002-p схвалено “Концепцію розвитку системи громадського здоров'я", яка визначає “систему громадського здоров'я” як комплекс інструментів, процедур та заходів, що реалізуються державними та недержавними інституціями для зміцнення здоров'я населення, запобігання захворюванням, продовження активного та працездатного віку й заохочення до здорового способу життя шляхом об'єднаних зусиль усього суспільства [3]. При цьому у Концепції належна увага приділена питанням розвитку кадрових ресурсів системи громадського здоров’я в країні.
3 метою виконання поставлених завдань важливо було вжити заходів щодо запровадження спеціальності “Громадське здоров'я" та подальшої спеціалізації та впровадження відповідних навчальних програм базової та післядипломної освіти. Уряд вніс зміни до постанови КМУ від 29 квітня 2015 р. № 266 "Про затвердження переліку галузей знань і спеціальностей, за якими здійснюється підготовка фахівців вищої освіти" щодо додаткового включення до переліку спеціальностей у галузі “Охорони здоров'я” спеціальності “Громадське здоров'я” (229). Варто вказати, що, на відміну від клінічних дисциплін, у рамках освоєння спеціальності “Громадське здоров'я” вивчається стан здоров'я не тільки окремих індивідів, а й колективів, соціальних груп і суспільства в цілому у зв'язку з умовами та способом життя, а МОН України затвердило освітній стандарт підготовки магістрів громадського здоров'я [4] та були розроблені освітні програми [5].

В основу програми повинні бути покладені кращі зарубіжні та вітчизняні практики й досвід у сфері профілактичної роботи (у тому числі закладів державної санітарно-епідеміологічної служби, центрів здоров'я, медичної статистики, соціального захисту населення та ін.), яка має забезпечити необхідні знання і сприяти максимальній практичній спрямованості навчання. Програма підготовки за спеціальністю "Громадське здоров'я" передбачає підготовку нової генерації фахівців для органів державного управління, місцевого самоврядування, суб'єктів господарювання різних форм власності, у тому числі недержавних організацій у сфері охорони громадського здоров'я. Навчальний план спеціальності 229 “Громадське здоров'я" містить сучасні дисципліни: громадське здоров'я, біостатистика, епідеміологія інфекційних та неінфекційних хвороб, управління ризиками, психічне здоров'я, паліативна й хоспісна допомога, промоція здоров'я та ін. 
Експерти відзначають, що найбільшу увагу державних та недержавних інституцій у сфері підготовки кадрів для національної системи громадського здоров'я необхідно зосередити на розвитку співпраці та партнерства 3 міжнародними організаціями, які тісно співпрацюють 3 ВОО3 та виробляють політику керівних принципів у підготовці кадрів для системи охорони здоров'я і трудових ресурсів загалом. Як приклад можна привести діяльність Асоціації шкіл охорони громадського здоров'я в Європейському регіоні (ASPHER) та Агентство 3 акредитації у сфері громадського здоров'я. ASPHER розробила список компетенцій, заснованих на європейському досвіді, рекомендованих європейськими школами громадської охорони здоров'я, представниками європейських міністерств охорони здоров'я i представниками робочої сили суспільної охорони здоров'я. Він включає списки компетенцій у всіх основних сферах практики суспільної охорони здоров'я, будь то робота у сфері обслуговування, викладання або дослідження та $є$ базою для основних елементів навчальної програми i подальшої перевірки навчальних програм [6].

Мета роботи - розробити шляхи оволодіння магістрами громадського здоров'я сучасними компетенціями.

\section{Матеріали та методи}

Використано методи: контент-аналізу, структурнологічного аналізу, описового моделювання. Матеріали дослідження: документи ВООЗ та України 3 питань підготовки магістрів громадського здоров'я та їх компетенції.

\section{Результати дослідження та їх обговорення}

На початку дослідження були проаналізовані компетенції, які затверджені стандартом вищої освіти за спеціальністю 229 «Громадське здоров'я» для другого (магістерського) рівня вищої освіти. Даним стандартом затверджено 14 загальних компетенцій, 12 спеціальних (фахових) компетенцій та додатково для освітньонаукових програм підготовки магістрів 2 додаткові спеціальні (фахові) компетенції.

Далі проаналізовано освітньо-наукову програму «Громадське здоров'я» другого (магістерського) рівня вищої освіти за спеціальністю 229 Охорона здоров'я ДВНЗ «Ужгородський національний університет». Даною програмою визначено набуття магістрами 17 загальних компетенцій та 19 спеціальних (фахових) компетенцій. Таким чином в університеті розширено як загальні, так i фахові компетенції у відповідності до функцій, які мають виконувати спеціалісти громадського здоров'я в своїй практичній діяльності.

В подальшому було проаналізовано рамки компетенцій WHO-ASPHER, які розроблено BOO3 у відповідності до основних оперативних функцій громадського здоров'я. Вказані ключові компетенцій громадського здоров'я були представлені Всесвітньою організацією охорони здоров'я (ВОО3) в Україні на семінарі в листопаді 2019 року. Участь у заході взяли представники директорату громадського здоров'я Міністерства охорони здоров'я, Центру громадського здоров'я України, регіональних центрів здоров'я та вищих навчальних закладів, що готують фахівців у сфері громадського здоров'я. В ході семінару було відмічено, що для формування системи громадського здоров'я в Україні важливо переймати досвід визнаних експертів цієї галузі. Варто зазначити, що методологія розвитку ключових компетенцій громадського здоров'я, розроблених ВООЗ та Асоціацією шкіл громадського здоров'я в Свропейському регіоні (ASPHER) надає змогу покращити розуміння та бачення того, які саме компетенції потрібні для виконання ключових функцій громадського здоров'я на різних адміністративних рівнях. Рамка компетенцій зосереджена на трьох основних категоріях: зміст і контекст, відносини i взаємодії, ефективність і досягнення і містить 84 компетенції.

Далі, в табл. 1, наведено взаємозв'язок вказаних компетенцій WHO-ASPHER та основних оперативних функцій громадського здоров'я (ОФГЗ).

Таблиця 1. Взасмозв'язок Рамки компетенцій WHO-ASPHER та основних оперативних функцій громадського здоров'я, розроблених ВООЗ

\begin{tabular}{|c|c|}
\hline ОФГЗ & Відповідна ключова компетенція \\
\hline \multirow{5}{*}{$\begin{array}{l}\text { ОФГЗ 1: } \\
\text { Епіднагляд і оцінка } \\
\text { стану здоров’я та } \\
\text { благополуччя } \\
\text { населення }\end{array}$} & $\begin{array}{l}\text { 1.1. Знає особливості демографічної структури в даному суспільстві/громаді та розуміє } \\
\text { процес демографічних змін та їх наслідки для громадського здоров'я (здоров'я населення) }\end{array}$ \\
\hline & $\begin{array}{l}\text { 1.2. Вміє описати ключові особливості епідеміології важливих причин захворюваності та } \\
\text { смертності населення, які знаходяться у сфері відповідальності }\end{array}$ \\
\hline & $\begin{array}{l}\text { 1.3. Ефективно використовує демографічну статистику та показники стану здоров’я для } \\
\text { збільшення знань та отримання доказів щодо здоров'я населення, в тому числі в групах } \\
\text { ризику та вразливих групах }\end{array}$ \\
\hline & $\begin{array}{l}\text { 1.5. Має обізнаність щодо потреб населення щодо здоров’я, на основі врахування тягаря } \\
\text { захворювань, показників, характеристики ризиків та попиту/доступу до медичної } \\
\text { допомоги }\end{array}$ \\
\hline & $\begin{array}{l}\text { 1.6. Сприяє або проводить оцінки потреб у сфері здоров’я на базі громади, забезпечуючи, } \\
\text { щоб ці оцінки враховували біологічні, соціальні, економічні, культурні, політичні, фізичні } \\
\text { детермінанти здоров’я та більш широкі детермінанти здоров'я такі як втрати }\end{array}$ \\
\hline
\end{tabular}




\section{ОФГЗ 2:}

Моніторинг i реагування на небезпеки для здоров'я та надзвичайні ситуації у сфері охорони здоров'я

\section{ОФГЗ 3:}

Захист здоров'я, включаючи забезпечення безпеки навколишнього середовища, праці і харчових продуктів та інше

\section{ОФГЗ 4:}

Зміцнення здоров'я, включаючи вплив на соціальні детермінанти і скорочення нерівності за показниками здоров'я
4.7. Знає та бере участь у розробці та застосуванні багатогалузевих доказових методичних рекомендацій та систем нагляду, профілактики та контролю захворювань та інших гострих подій у сфері громадського здоров'я

4.8. Здійснює нагляд за ризиками та загрозами у рамках повного контінууму факторів, які впливають на стан здоров'я та визначають його, з метою виявлення потреб у заходах

3.5. Розробляє та впроваджує стратегії на основі відповідних доказів, законодавства, процедур планування надзвичайних ситуацій, регламентів та політики

4.1. Розуміє локальні наслідки підходу «Єдине здоров'я», його глобальний взаємозв'язок та його вплив на здоров'я

4.2. Критично аналізує мінливу природу, основні фактори та ресурси, які формують «Сдине здоров'я», щоб впливати на дії (планування готовності до надзвичайних ситуацій та реагування на них) на місцевому та міжнародному рівнях

4.3. Знає, і де потрібно застосовує, Міжнародні медико-санітарні правила для координації та розвитку стратегічного партнерства та ресурсів у ключових секторах та дисциплінах для цілей безпеки здоров'я

4.7. Знає те бере участь у розробці та застосуванні багатогалузевих доказових методичних рекомендацій та систем нагляду, профілактики та контролю захворювань та інших гострих подій у сфері громадського здоров'я

4.8. Здійснює нагляд за ризиками та загрозами у рамках повного контінууму факторів, які впливають на стан здоров'я та визначають його, з метою виявлення потреб у заходах

3.1. Знає, розуміє та застосовує відповідні міжнародні, європейські та національні закони чи постанови для максимізації можливостей для захисту та зміцнення здоров’я та благополуччя

4.1. Розуміє локальні наслідки підходу «Єдине здоров’я», його глобальний взаємозв’язок та його вплив на здоров'я

4.4. Розуміє та сприяє безпеці та гігієні праці як багатопрофільній галузі, що стосується безпеки, здоров'я та добробуту людей на роботі

4.5. Знає практичні принципи безпеки харчових продуктів, Суттєві для здоров'я населення

4.6. Розуміє основи профілактики вакцинокерованих захворювань та вміє консультувати 3 організаційних аспектів вакцинації

4.7. Знає та бере участь у розробці та застосуванні багатогалузевих доказових методичних рекомендацій та систем нагляду, профілактики та контролю захворювань та інших гострих подій у сфері громадського здоров'я

4.8. Здійснює нагляд за ризиками та загрозами у рамках повного контінууму факторів, які впливають на стан здоров'я та визначають його, з метою виявлення потреб у заходах

4.9. Визначає мінімальні або основні умови безпеки при наданні медичної допомоги для розробки та реалізації програм та заходів щодо спостереження, управління ризиками та сталості, властивих наданню медичних послуг

4.10. Визначає та описує екологічні детермінанти здоров'я та зв'язки між охороною навколишнього середовища і політикою у сфері громадського здоров'я

4.11. Знає і правильно визначає основні особливості процесу зміни клімату, а також його наслідки для громадського здоров'я та розуміє відповідальність громадського здоров'я за природне середовище

2.1. Оцінює фокус та обсяг ініціатив щодо зміцнення здоров'я шляхом оцінки потреби у досягненні позитивних змін у здоров'ї окремих індивідів та громад

2.2. Знає, підтримує та залучається до заходів, пов'язаних зі зміцненням здоров'я та медичною грамотністю, та програм виконання гарних практик для зміцнення здоров'я на рівні населення та рівні конкретної організації або інституційному рівні

2.3. Використовує доказові методи та стратегії, соціальну участь та міжгалузеві підходи як інструменти зміцнення здоров'я та впливу на державну політику, що впливає на здоров'я

2.4. Оцінює ефективність заходів зі зміцнення здоров'я, спрямованих на досягнення змін на рівні громади та особистості у державній чи соціальній політиці для покращення здоров’я та якості життя 
ОФГЗ 5:

Профілактика хвороб, включаючи раннє виявлення

\section{ОФГЗ 6:}

Забезпечення стратегічного керівництва в інтересах здоров'я та благополуччя
2.5. Сприяє розширенню можливостей громадян та їх залученню до громади, розвиваючи можливості, які є цінними для активної участі у розвитку та прийнятті рішень здорової громади

2.6. У разі необхідності підготовляє або оприлюднює фактичну інформацію для протидії галузевому маркетингу стосовно: харчування, припинення тютюнопалінння, скорочення споживання алкоголю тощо

2.8. Розуміє та вирішує основні причини нерівностей у сфері здоров'я та пов'язані з ними наслідки (такі як наркоманія, зловживання алкоголем, куріння) у забезпечені справедливого доступу до медичних послуг

5.8. Каталізує зміни (поведінкові та/або культуральні) в організації, громаді та/або окремих людях

7.8. Впливає на здорову державну політику та послуги, що сприяють та захищають здоров’я та благополуччя людей та громад

2.6. У разі необхідності підготовляє або оприлюднює фактичну інформацію для протидії галузевому маркетингу стосовно: харчування, припинення тютюнопалінння, скорочення споживання алкоголю тощо

\section{7. Знає основи програм вторинної профілактики та скринінгу}

2.8. Розуміє та вирішує основні причини нерівностей у сфері здоров'я та пов'язані з ними наслідки (такі як наркоманія, зловживання алкоголем, куріння) у забезпечені справедливого доступу до медичних послуг

4.4. Розуміє та сприяє безпеці та гігієні праці як багатопрофільній галузі, що стосується безпеки, здоров'я та добробуту людей на роботі

4.6. Розуміє основи профілактики вакцинокерованих захворювань та вміє консультувати з організаційних аспектів вакцинації

4.7. Знає те бере участь у розробці та застосуванні багатогалузевих доказових методичних рекомендацій та систем нагляду, профілактики та контролю захворювань та інших гострих подій у сфері громадського здоров'я

1.10. Розуміс структуру системи охорони здоров'я, іiі управління, механізми фінансування та організацію медичних послуг

3.1. Знає, розуміє та застосовує відповідні міжнародні, європейські та національні закони чи постанови для максимізації можливостей для захисту та зміцнення здоров’я та благополуччя

3.2. Застосовує наукові принципи та концепції для підготовки інформації для обговорень пов'язаних із охороною здоров'я фінансових, адміністративних, правових, соціальних та політичних питань на робочому місці

3.3. Порівнює та протиставляє системи надання медичних та соціальних послуг між країнами, які відображають різноманітні політичні, організаційні та правові контексти, використовуючи цей досвід для покращення доступу до системи охорони здоров’я, їх регулювання та справедливості

3.4. Бере участь у реалізації медичної та соціальної політики та планів, які допомагають гарантувати право на справедливу та ефективну охорону здоров’я, та політик, що сприяють створенню сприятливого для здоров'я середовища

3.5. Розробляє та впроваджує стратегії на основі відповідних доказів, законодавства, процедур планування надзвичайних ситуацій, регламентів та політики

3.6. Визначає та використовує законодавство, кодекси етичної практики та стандарти, які впливають на професійну практику у взаємодії з окремими особами, організаціями та громадянами у сфері громадського здоров'я

5.5. Демонструє емоційний інтелект із усвідомленням впливу власних переконань, цінностей та поведінки на власне прийняття рішень та на реакції інших

5.6. Демонструє практичність, гнучкість та пристосованість у процесі роботи з іншими, акцентуючи на пріоритетності досягнення цілей на відміну від жорсткого дотримання традиційних і широко використовуваних методів роботи

5.9. Розуміє принципи системного мислення та здатний застосовувати їх у рамках системного дослідження для аналізу, моделювання та вдосконалення організацій та служб громадського здоров'я на різних стратегічних рівнях 
6.6. Розуміє та застосовує ефективні методи роботи з правліннями та структурами управління, включаючи регулярні, професійні та акредитаційні агенції

8.1. Ефективно застосовує знання про організаційні системи, теорії та поведінку з метою пріоритизації, узгодження та розширення всіх відповідних ресурсів для досягнення чітких стратегічних цілей та завдань

8.2. Ефективно керує людьми зокрема, зокрема завдяки визначенню чіткої відповідальності за виконання завдань, забезпеченню достатніх ресурсів та навчань, а також регулярного зворотнього зв'язку щодо виконання

8.3. Ефективно планує розподіл робочих завдань для досягнення поставлених організацією цілей

8.5. Демонструє знання основних-базіс практик, таких як технічне завдання, бізнес-плани, укладання договорів та управління проектами

8.6. $С$ проактивним у розробці та моніторингу стандартів якості та застосовує методи та інструменти підвищення якості для виявлення внутрішніх та зовнішніх стимулюючих факторів та бар'єрів, які можуть вплинути на виконання десяти основних оперативних функцій громадського здоров'я

8.8. Ефективно використовує принципи та програми управління ризиками, такі як оцінка та аналіз ризиків

9.3. Діє добросовісно відповідно до етичних стандартів та норм, сприяє професійній підзвітності, соціальній відповідальності та громадському благу

9.7. Демонструє здатність розуміти та керувати ситуаціями конфлікту інтересів у відповідності до визначених положень, політик та процедур організації

10.4. Активно готується та адаптується до мінливих професійних умов та обставин

10.6. Застосовує методології, (цифрові) технології та передовий досвід управління, аналізу та зберігання даних та медичної інформації

\section{ОФГЗ 7:}

Забезпечення сфери громадського здоров'я кваліфікованими кадрами в достатній кількості

\section{1. Надихає та мотивує інших працювати над спільним баченням, програмою та/або цілями}

5.2. Виступає прикладом для наслідування, будує довіру і демонструє позитивну та заохочувальну поведінку

\section{3. Сприяє розвитку інших як лідерів}

5.4. Чітко визначає та підтримує роль та обов'язки всіх членів команди, включаючи зовнішніх зацікавлених сторін

5.5. Демонструє емоційний інтелект із усвідомленням впливу власних переконань, цінностей та поведінки на власне прийняття рішень та на реакції інших

5.7. Ефективно спонукає міждисциплінарні команди координувати роботу в різних сферах практики громадського здоров'я

8.2. Ефективно керує людьми зокрема, зокрема завдяки визначенню чіткої відповідальності за виконання завдань, забезпеченню достатніх ресурсів та навчань, а також регулярного зворотнього зв'язку щодо виконання

8.4. Розробляє посадові інструкції для забезпечення персоналу на різних організаційних рівнях, проводить співбесіди та оцінює кандидатів

9.1. Демонструє готовність продовжувати навчання у сфері громадського здоров’я протягом усього життя

9.2. Проводить самооцінку та вирішує власні потреби розвитку на основі цілей кар'єри та необхідних компетенцій

9.4. Критично переглядає, оцінює власну практику стосовно принципів громадського здоров'я, включаючи критичну саморефлексію

9.6. Забезпечує наявність можливостей професійного розвитку

10.2. Демонструє постійність, наполегливість і стійкість, та здатність залучати особисті ресурси та енергію під час загрози чи виклику

10.3. Здатний впоратися з невизначеністю та управляти робочим стресом 


\section{ОФГЗ 8:}

Забезпечення функціонування організаційних структур та фінансування

\section{ОФГЗ 9:}

Інформаційнороз'яснювальна діяльність (адвокація), комунікація та соціальна мобілізація в інтересах здоров'я
1.1. Знає особливості демографічної структури в даному суспільстві/громаді та розуміє процес демографічних змін та їх наслідки для громадського здоров'я (здоров'я населення) 3.2. Застосовує наукові принципи та концепції для підготовки інформації для обговорень пов'язаних із охороною здоров'я фінансових, адміністративних, правових, соціальних та політичних питань на робочому місці

3.3. Порівнює та протиставляє системи надання медичних та соціальних послуг між країнами, які відображають різноманітні політичні, організаційні та правові контексти, використовуючи цей досвід для покращення доступу до системи охорони здоров’я, їх регулювання та справедливості

5.7. Ефективно спонукає міждисциплінарні команди координувати роботу в різних сферах практики громадського здоров'я

6.2. Розуміє взаємозалежність, інтеграцію та конкуренцію між секторами охорони здоров'я та різники суб'єктами, які мають інтереси у питаннях громадського здоров'я

8.1. Ефективно застосовує знання про організаційні системи, теорії та поведінку з метою пріоритизації, узгодження та розширення всіх відповідних ресурсів для досягнення чітких стратегічних цілей та завдань

8.5. Демонструє знання основних-базіс практик, таких як технічне завдання, бізнес-плани, укладання договорів та управління проектами

8.7. Ефективно використовує ключові принципи звітності та інструменти фінансового менеджменту, такі як фінансові плани та оцінка ефективності роботи

8.9. Розуміє та застосовує принципи економічного мислення у сфері громадського здоров'я

8.10. Виконує оцінку економіки охорони здоров'я та оцінку певної процедури, заходу, стратегії чи політики

10.1. Демонструє підприємницьку орієнтацію через проактивність, інноваційність, ризикованість, генерацію потенційних рішень у критичних ситуаціях та оцінку їх доцільності

10.4. Активно готується та адаптується до мінливих професійних умов та обставин

10.8. Знає про існування і знає як подати заявки на наявні джерела та можливості фінансування, відповідає на заявки на проекти, розробляє та подає заявки та гранти на проекти, розробляє тендер та стислі описи на проекти

2.2. Знає, підтримує та залучається до заходів, пов'язаних зі зміцненням здоров'я та медичною грамотністю, та програм виконання гарних практик для зміцнення здоров'я на рівні населення та рівні конкретної організації або інституційному рівні

2.3. Використовує доказові методи та стратегії, соціальну участь та міжгалузеві підходи як інструменти зміцнення здоров'я та впливу на державну політику, що впливає на здоров'я

2.5. Сприяє розширенню можливостей громадян та їх залученню до громади, розвиваючи можливості, які $є$ цінними для активної участі у розвитку та прийнятті рішень здорової громади

2.6. У разі необхідності підготовляє або оприлюднює фактичну інформацію для протидії галузевому маркетингу стосовно: харчування, припинення тютюнопалінння, скорочення споживання алкоголю тощо

5.8. Каталізує зміни (поведінкові та/або культуральні) в організації, громаді та/або окремих людях

6.1. Працює в різних секторах в організаційних структурах на місцевому/національному/ міжнародному рівнях

6.3. Виявляє, з’єднує та керує взаємовідносинами із зацікавленими сторонами в міждисциплінарних та міжгалузевих проектах для покращення послуг громадського здоров'я та досягнення цілей громадського здоров'я

6.4. Створює, підтримує та ефективно використовує стратегічні альянси, коаліції, професійні мережі та партнерства для планування, отримання доказів та реалізації програм та служб, які поділяють загальні цілі та пріоритети для покращення здоров'я та благополуччя населення

6.5. Оцінює партнерські стосунки та усуває перешкоди для успішної співпраці з метою вдосконалення послуг громадського здоров'я 
7.1. Спілкується стратегічно, визначаючи цільову аудиторію, слухаючи та розробляючи відповідні до аудиторії повідомлення

7.2. Ефективно спілкується, обмінюється інформацією та поділяє відповідальність на різних організаційних рівнях для отримання політичної прихильності, підтримки політики та соціального прийняття певної мети чи програми, пов'язаних зі здоров'ям

7.3. Ефективно повідомляє про факти та доказів контексті втілення доказів у практику та політику для різних суб'єктів системи та неблагополучних верств населення, зокрема, для підвищення ефективності реагування на ризики, загрози та шкоду здоров'я

7.4. Ефективно (як письмово так і усно) передає повідомлення про здоров'я (включаючи ризики для здоров'я) за допомогою різноманітних сучасних засобів масової інформації та соціального маркетингу для широкої, професійної, академічної та політичної аудиторії

7.5. Розуміє та застосовує культурну обізнаність та чутливість у спілкуванні з різними групами населення

7.6. 3 повагою спілкується, представляючи професійні думки, та заохочує інших членів команди, включаючи членів громади та пацієнтів, висловлюючи свою думку та сприяти прийняттю рішень

7.7. Готує та подає матеріали для полегшення спілкування всередині та між організаціями, такі як порядок денний зустрічей, презентації, звіти та проекти

10.7. Розуміє та застосовує ряд відповідних засобів інформаційних технологій, соціальних медіа та програмного забезпечення

\section{ОФГЗ 10:}

Сприяння розвитку досліджень в галузі суспільного здоров'я для наукового обгрунтування політики і практики
1.3. Ефективно використовує демографічну статистику та показники стану здоров'я для збільшення знань та отримання доказів щодо здоров'я населення, в тому числі в групах ризику та вразливих групах

1.4. Знає, як отримати, проаналізувати та оцінити докази з усіх джерел даних для підтримки прийняття рішень

1.7. Розробляє та проводить якісні та/або кількісні дослідження, які грунтуються на існуючих доказах та доповнюють базу доказів для практики громадського здоров'я, залучаючи до цього процесу відповідних зацікавлених сторін

1.8. Оцінює місцеві служби громадського здоров'я, застосовуючи обгрунтовану методологію на основі визнаних моделей оцінювання

1.9. Розробляє та впроваджує стандарти, протоколи та процедури, які містять національні та/або міжнародні «найкращі практики» в системі охорони здоров'я

2.4. Оцінює ефективність заходів зі зміцнення здоров'я, спрямованих на досягнення змін на рівні громади та особистості у державній чи соціальній політиці для покращення здоров'я та якості життя

9.5. Діє та просуває професійну практику на основі доказів
Для набуття магістрами відповідних компетенцій освітня програма складається із 17 обов'язкових компонентів (86,5 кредитів) та 9 компонентів за вибором (33,5 кредитів). При цьому обов’язкові компоненти мають забезпечити набуття магістрами необхідних компетенцій для їх майбутньої професійної діяльності.

Нами проведене співставлення компонентів освітньої програми та компетенцій, які розроблені ВООЗ щодо можливості їх набуття в освітньому процесі (табл. 2).

Таблиця 2. Матриця забезпечення компонентами освітньої програми Ужгородського національного університету набуття магістрами компетенцій

\begin{tabular}{|l|c|l|}
\multicolumn{1}{|c|}{ Компоненти освітньої програми } & $\begin{array}{c}\text { Кількість } \\
\text { кредитів }\end{array}$ & Компетенції кадрів громадського здоров'я \\
\hline Вступ до спеціальності «Громадське здоров'я» & 4,5 & $1.1 ; 1.5 ; 1.6 ; 1.9 ; 3.1 ; 3.6 ; 4.2 ; 4.10 ; 8.1 ; 10.2$ \\
\hline Біостатистика & 4,0 & $1.1 ; 1.3 ; 1.4 ; 1.7 ; 1.8 ; 2.3 ; 2.4 ; 3.5 ; 8.10 ; 9.5$ \\
\hline Ділова англійська мова & 3,0 & $3.1 ; 3.3$ \\
\hline Організація охорони здоров'я в Україні & 4,0 & $1.5 ; 1.10 ; 3.2 ; 3.3 ; 6.2 ; 8.1 ; 8.10$ \\
\hline Профілактика в системі громадського здоров'я & 4,5 & $2.2 ; 2.6 ; 2.7 ; 4.5 ; 4.6 ; 4.7 ; 2.10 ; 8.8$ \\
\hline Основи епідеміології & 3,0 & $1.2 ; 1.6 ; 4.4 ; 4.5 ; 4.6$ \\
\hline Епідеміологія неінфекційних хвороб & 3,5 & $1.2 ; 1.3 ; 1.5 ; 1.10 ; 4.2 ; 4.3 ; 4.8$ \\
\hline
\end{tabular}




\begin{tabular}{|c|c|c|}
\hline Епідеміологія інфекційних хвороб & 3,0 & $1.2 ; 1.3 ; 4.1 ; 4.3 ; 4.5 ; 4.8$ \\
\hline Інформатизація та комунікації в охороні здоров’я & 4,0 & $\begin{array}{l}2.6 ; 3.3 ; 3.6 ; 5.5 ; 5.6 ; 6.3 ; 6.5 ; 7.1 ; 7.2 ; 7.3 ; 7.4 ; \\
7.5 ; 7.6 ; 7.7 ; 10.6 ; 10.7\end{array}$ \\
\hline Організація та презентація наукових досліджень & 4,0 & $1.4 ; 1.7 ; 1.8 ; 1.9 ; 2.3 ; 3.2 ; 10.6$ \\
\hline Наукові комунікації у галузі громадського здоров’я & 4,0 & $2.3 ; 3.6 ; 5.9 ; 7.3 ; 8.1 ; 10.6$ \\
\hline Політика, етика, лідерство в громадському здоров’ї & 3,0 & \\
\hline Програмний менеджмент в громадському здоров 'ї & 4,0 & $\begin{array}{l}1.3 ; 2.1 ; 2.4 ; 2.8 ; 3.4 ; 3.5 ; 3.6 ; 4.7 ; 4.9 ; 5.6 ; 5.7 \\
5.9 ; 6.6 ; 8.1 ; 8.2 ; 8.3 ; 8.5 ; 8.6 ; 8.7 ; 8.9 ; 8.10 ; 9.3 ; \\
9.7 ; 10.4 ; 10.6\end{array}$ \\
\hline Управління якістю життя & 4,0 & $2.2 ; 2.4 ; 3.4 ; 5.8 ; 8.8$ \\
\hline Моніторинг та оцінка в системі громадського здоров’я & 4,0 & $1.1 ; 1.2 ; 1.3 ; 1.7 ; 2.4 ; 4.4 ; 4.8 ; 9.5$ \\
\hline Науково-дослідна практика & 6,0 & \\
\hline Виконання кваліфікаційної роботи & 21,0 & \\
\hline
\end{tabular}

Проведений аналіз співставлення компонентів освітньої програми Ужгородського національного університету та компетенцій, які розроблені ВООЗ щодо можливості їх набуття в освітньому процесі дозволили зробити висновки, що в період навчання магістри набувають основні визначені компетенцї, що навезено в табл.2, в період навчання, а інші компетенції вони мають набувати в процесі післядипломної освіти в залежності від посади які вони замають.

3 метою освоєння магістрами зазначених компетенцій рекомендується використовувати методи навчання, класифікацію яких запропонував О.М. Алексюк:

а) зовнішньої формою прояву навчання:

- словесні методи навчання: лекція, бесіда, розповідь, пояснення, дискусії, робота з книгою;

- наочні методи: ілюстрування, демонстрування, спостереження;

- практичні методи: самостійна робота, вправи, лабораторний досвід;

б) внутрішньою формою прояву навчання:

- за характером пізнавальної діяльності студентів: репродуктивні, пояснювально-ілюстративні, проблемні, частково-пошукові, дослідницькі;

- за характером логічного шляху мислення: індуктивні, дедуктивні, традуктивні (аналогіi);

- за принципом роз'єднання чи об'єднання знань: аналіз, синтез, порівняння, узагальнення, класифікація.
Широко рекомендується застосовувати активні та інтерактивні методи навчання. А сучасними формами навчання мають виступати інформаційна та проблемна лекція, лекція-візуалізація, бінарна лекція, лекціядискусія, лекція із заздалегідь запланованими помилками, лекція-консиліум або конференція, ділова гра, лабораторний практикум.

Перспективи подальших досліджень пов'язані 3 вивченням рівня самооцінки викладачами вищих навчальних закладів, що готують фахівців у сфері громадського здоров'я та працівниками регіональних центрів здоров'я володіння вказаними компетенція ми за методикою, що рекомендована ВОО3.

\section{Висновки}

За результатами дослідження рекомендується узгодити компетенції для кадрів громадського здоров'я, які розробила ВООЗ та визначені стандартом вищої освіти i освітніми програмами в Україні. Проаналізований навчальний план освітньо-наукової програми магістратури за спеціальністю «Громадське здоров'я» підлягає корекції по забезпеченню оволодіння особами, що навчаються сучасними компетенціями відповідно до основних оперативних функцій громадського здоров'я. В навчальному процесі рекомендується широко застосовувати сучасні методи та форми навчання.

\section{Література}

1. Европейский план действий по укреплению потенциала и услуг общественного здравоохранения. Копенгаген: Европейское региональное бюро ВО3, (документ EUR/RC62/12), 2012.52 с.

2. Основы Европейской политики поддержки государства и общества в интересах здоровья и благополучия. Копенгаген: Европейское региональное бюро ВО3, (документ EUR/RC62/12). 2012. Доступно 3: http://www.euro.who.int/ PubRequest?language=Russian.

3. Про схвалення Концепції розвитку системи громадського здоров'я: Розпорядження Кабінету Міністрів України №1002-р від 30.11.2016 Доступно 3: https://zakon.rada.gov.ua/laws/show/1002-2016-\%D1\%80.

4. Про затвердження стандарту вищої освіти за спеціальністю 229 «Громадське здоров'я» для другого (магістерського) рівня вищої освіти. Наказ Міністерства освіти і науки України №1383 від 12.12 .2018 р. Доступно з: https://mon.gov.ua/storage/app/media/vishcha-osvita/rekomendatsii-1648.pdf. 
5. Освітньо-наукова програма «Громадське здоров’я» другого (магістерського) рівня вищої освіти за спеціальністю 229 Охорона здоров’я. Затверджено Вченою радою ДВНЗ «Ужгородський національний університет». Протокол №4 від 21.03.2019 p.

6. Рамки компетенцій WHO-ASPHER для кадрів громадського здоров'я в Європейському регіоні. Проект. Копенгаген: Європейське регіональне бюро BOO3, ASPHER. Жовтень 2019.

\section{References}

1. Europeyskiy plan deystviy po ukrepleniyu potentsiala i uslug obshchestvennogo zdravookhraneniya. Copenhagen, WHO Regional Office for Europe, 2012 (document EUR/RC62/12). - $52 \mathrm{~s}$.

2. Osnovy europeyskoy politiki podderzhki gosudarstva i obshchestva $\mathrm{v}$ interesakh zdorovya $\mathrm{i}$ blagopoluchiya. Copenhagen. WHO Regional Office for Europe. 2012. Retrieved from: http://www.euro.who.int/PubRequest?language= Russian.

3. Pro skhvalennia Kontseptsii rozvytku systemy hromadskoho zdorovia: Rozporiadzhennia Kabinetu Ministriv Ukrainy №1002-r. vid 30.11.2016. Retrieved from: https://zakon.rada.gov.ua/laws/show/1002-2016-\%D1\%80.

4. Pro zatverdzhennja standartu vyshhoji osvity za specialjnistju 229 «Ghromadsjke zdorov'ja» dlja drughogho (maghistersjkogho) rivnja osvity, Nakaz Ministerstva osvity i nauky Ukrajiny №1383 vid 12.12.2018. Retrieved from: https://mon.gov.ua/storage/app/media/vishcha-osvita/rekomendatsii-1648.pdf.

5. Osvitno-naukova prohrama «Hromadske zdorovia» druhoho (mahisterskoho) rivnia vyshchoi osvity za spetsialnistiu 229 Okhorona zdorovia. Zatverdzheno Vchenoiu radoiu DVNZ «Uzhhorodskyi natsionalnyi universytet». Protokol № 4 vid 21.03.2019 r.

6. Ramky kompetentsii WHO-ASPHER dlia kadriv hromadskoho zdorovia v Yevropeiskomu rehioni. Proekt. Copenhagen, WHO Regional Office for Europe, ASPHER. Zhovten 2019.

Дата надходження рукопису до редакції: 13.01 .2020 p.

Мета роботи - розробити шляхи оволодіння магістрами громадського здоров'я сучасними компетенціями.

Матеріали та методи. Використано методи: контент-аналізу, структурно-логічного аналізу, описового моделювання. Матеріали дослідження: документи ВООЗ та України з питань підготовки магістрів громадського здоров'я та їх компетенції.

Результати. Встановлена невідповідність компетенцій кадрів громадського здоров'я, які розробила ВООЗ та які визначені стандартом вищої освіти і освітніми програмами в Україні. Навчальний план освітньо-наукової програми магістратури нерівномірно забезпечує оволодіння магістрами сучасними компетенціями відповідно до основних оперативних функцій громадського здоров'я.

Висновки. Узгодити компетенції для кадрів громадського здоров'я, які розробила ВООЗ та визначені стандартом вищої освіти і освітніми програмами підготовки магістрів в Україні. Проаналізований навчальний план освітньонаукової програми магістратури за спеціальністю «Громадське здоров’я» підлягає корекції по забезпеченню оволодіння особами, що навчаються сучасними компетенціями відповідно до основних оперативних функцій громадського здоров’я. В навчальному процесі рекомендується широко застосовувати сучасні методи та форми навчання.

Ключові слова: громадське здоров’я, магістри, компетенції, оволодіння.

Цель работы - разработать способы овладения магистрами общественного здравоохранения современными компетенциями.

Материалы и методы. Использованы методы: контент-анализа, структурно-логического анализа, описательного моделирования. Материалы исследования: документы ВО3 и Украины по вопросам подготовки магистров общественного здравоохранения и их компетенции.

Результаты. Установлено несоответствие компетенций кадров общественного здравоохранения, которые разработаны ВО3 и утверждены стандартом высшего образования и образовательными программами в Украине. Учебный план научно-образовательной программы магистратуры неравномерно обеспечивает овладение магистрами современными компетенциями в соответствии с основными оперативными функциями общественного здравоохранения.

Выводы. Согласовать компетенции для кадров общественного здравоохранения, которые разработаны ВОЗ и утверждены стандартом высшего образования и образовательными программами в Украине. Проанализированный учебный план научно-образовательной программы магистратуры по специальности «Общественное здравоохранение» подлежит коррекции для обеспечения овладения лицами, которые обучаются, современными компетенциями в соответствии с основными оперативными функциями общественного здравоохранения.

Ключевые слова: общественное здравоохранение, магистры, компетенции, овладение. 
The aim of the work if to develop ways of mastering modern competencies by public health masters.

Materials and methods. Methods used: content analysis, structural and logical analysis, descriptive modelling. Study Materials: WHO and Ukraine documents on training public health masters and their competencies.

Results. We have found a discrepancy between the competencies of public health professionals developed by WHO and those defined by the higher education standard and educational programs in Ukraine. The curriculum of the master's degree program unevenly assures master's acquiring modern competencies according to the basic operational functions of public health.

Conclusions. It is needed to reconcile competencies for public health professionals developed by WHO and those defined by higher education standards and educational programs in Ukraine. The analyzed curriculum of Master's degree program in the specialty "Public Health" is subject to adjustments to ensure that students have acquired modern competencies in accordance with the basic operational functions of public health.

Key words: public health, masters, competencies, mastering.

Конфлікт інтересів: відсутній.

Conflicts of interest: authors have no conflicts of interest to declare.

\section{Відомості про авторів}

Слабкий Геннадій Олексійович - доктор медичних наук, професор, завідувач кафедри наук про здоров'я ДВНЗ «Ужгородський національний університет»; площа Народна, 1, м. Ужгород, Україна, 88000. +380(50) 171-16-48, g.slabkiy@ukr.net.

Миронюк Іван Святославович - доктор медичних наук, доцент, декан факультету здоров’я та фізичного виховання ДВНЗ «Ужгородський національний університет»; площа Народна, 1, м. Ужгород, Україна, 88000. +380 (50) 692-72-20, ivan.myronyuk@uzhnu.edu.ua.

Білак-Лук'янчук Вікторія Йосипівна - кандидат медичних наук, доцент кафедри наук про здоров'я ДВНЗ «Ужгородський національний університет»; площа Народна, 1, м. Ужгород, Україна, 88000.

+380(50) 597-05-99, bilak.vika@gmail.com. 